\title{
TECHNICAL SERVICE PROVIDERS: WHAT'S THE POTENTIAL?
}

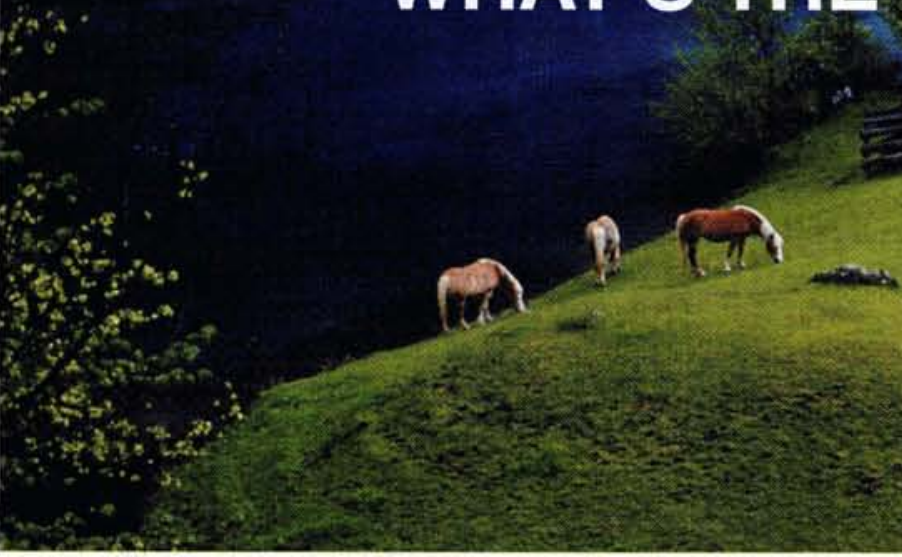

Strengthening the Nation's conservation technical services infrastructure has been identified as the greatest opportunity to enhance conservation on working lands in a recent Soil and Water Conservation Society report. The report-based on the input from producers and stakeholders-made the recommendation that strengthening technical services should be a primary objective of the Farm Security and Rural Investment Act of 2002, more commonly referred to as the farm bill. Congress took a step to strengthen technical services when it directed the Secretary to establish a program that facilitates the use of technical assistance from public and/or private sectors to implement U.S. Department of Agriculture (USDA) conservation programs.

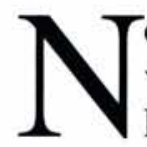

ovember 21, an interim rule for technical service provider assistance was published in the Federal Register. Public comment is being requested by February 10, 2003. This program could define or muddy that technical services infrastructure. What are the issues surrounding this technical service provider initiative?

\section{A foundation to build on}

USDA's Natural Resources Conservation Service (NRCS) provides technical expertise and education to producers to help them make land management decisions. When a producer applies to participate in a USDA conservation program, NRCS helps the producer evaluate the resource conditions on their land to determine the most appropriate way to meet the producer's conservation objectives. It's widely acknowledged both inside and outside NRCS that they haven't been able to keep up with the technical assistance demands over the last few years.

Add to this that the farm bill allocates a record $\$ 13$ billion for conservation over the next six years and you have a situation where additional help is needed. NRCS staff roughly estimates that 30 to 40 percent of the technical services needed to implement programs created by this latest farm bill will have to come from private and public entities. In order to accomplish the technical and administrative workload of the farm bill, NRCS will build on its traditional partnerships and establish new bonds with private technical service providers. Traditional partners include conservation districts, nonprofits, or state conservation agencies. And private technical service providers-also called third party vendors-are independent agricultural consultants, farmers, and anyone who can be NRCS certified as a technical service provider. 
There are limitations and benefits to this approach. Turning to the private sector is a risk because there isn't a framework developed to the degree needed. There are serious concerns about the availability and technical skills of private technical service providers. One bright spot may be the partners already engaged in the existing infrastructure because they are eligible as technical service providers. These partners include conservation districts, the public sector, such as state conservation agencies or state fish and wildlife agencies, and nonprofits.

When speaking of the farm bill Chief of NRCS Bruce Knight says, "It's the single most significant commitment of resources for conservation on private lands in the Nation's history. It's too big for NRCS to tackle alone. We need to build an industry to get the job done."

The industry Chief Knight wants to build pays technical service providers through conservation programs like the Environmental Quality Incentives Program (EQIP) and the Conservation Reserve Program (CRP) to provide technical assistance to landowners.

The Soil and Water Conservation Society's Executive Director Craig Cox is cautiously optimistic, "My greatest hope is that the technical service provider program will allow us to create technical service teams at the local level that can provide the multidisciplinary technical assistance producers need today. My greatest fear is that the program will divert attention and possibly resources from the urgent need to strengthen the technical capacity within NRCS at all levels. NRCS can't do the job alone, but neither can technical service providers. We need to build up both sides of this new partnership, or it just won't work."

NRCS was given the responsibility of miring through the thorny details of how this will work. There are concerns that NRCS won't be able to pull this off. Some see this as asking the agency to create an industry that will compete with itself revealing some of the agency's shortcomings or creating pressure to downsize.

Chief Knight says the intent is not to replace NRCS employees, but supplement them in a very big way.

\section{How does it work?}

A portion of the thorny details can be found in the interim rule that is posted on the NRCS website at www.nrcs.usda.gov/news/tsp_rule.html but the general strategy is straightforward. A technical service provider can be from the private or public sectors. Private consultants, employees of agribusiness and anyone who can be NRCS certified as a technical service provider can be approved. Employees of natural resource conservation agencies, departments, or other entities organized under local, state, or federal law who provide technical assistance as part of their jobs also can be approved. "We want to engage anyone who can help farmers," says Carole Jett, NRCS associate deputy chief. Conservation districts can participate, but in order to get technical service provider payments they will have to add or re-assign staff. "We want a net increase in conservation not a shuffling of resources," Jett says.

NRCS state conservationists will establish who qualifies to be certified as a technical service provider. Certification will be specific to a conservation practice or it's components if it's a complex process. "We want to make the certification flexible and adaptable to state conditions," says Rick Swenson, NRCS East regional conservationist. When a producer signs up for a program be it EQIP or CRP, NRCS will provide lists of approved technical service providers, as well as the local NRCS office. These lists will also be posted on NRCS websites. "The landowner will be clear on who can do what," says Swenson. "Producers can choose who they want."

Training and educational programs for technical service providers will be set up as needed. Land grant institutions, professional organizations, and NRCS will do the training.

There are two mechanisms for a technical service provider to receive payments. The first has landowners paying their technical service providers directly out of the money they receive from conservation programs like EQIP, CRP, the Wetlands Reserve Program, or the Wildlife Habitat Incentives Program for the technical services received. In most cases, technical service 
providers will bill the producer they worked for. The second mechanism is the technical service provider being hired as an agent for NRCS.

Payment amounts have not been established yet but NRCS was to publish an amendment to the interim rule by the end of 2002 that would explain in detail the payment rate process. NRCS is considering at least three options to set payment rates and is relying on information from public comments to ensure competitive payment rates for the most qualified technical service providers. The interim rule states that one method NRCS is considering is establishing payment rates by conducting a state-bystate solicitation of technical service prices from providers in order to verify current market prices for service delivery.

Another option NRCS is considering is basing technical service payments upon a flat rate for each project. For example, if a project costs $\$ 20,000$ to install, the program participant will be reimbursed $\$ 4,000$, or 20 percent of the project cost, for the technical services. Drawbacks of this approach include the questions surrounding the complexities of some projects or the fact that actual cost is not weighed for the project.

The third option is to consider basing technical service payment rates on NRCS's cost to deliver the technical services. To encourage competition, NRCS is also considering options to create incentives for producers to choose the most cost efficient provider of technical services in the market place. Rate adjustments will be periodically made.

There is plenty of flexibility for other arrangements, assures Jett. For example co-operative agreements with contributors covering 50 percent or more of the costs as currently done with organizations like Ducks Unlimited in the Wetland Reserve Program. NRCS will also contract directly with private companies and use official request for proposal procedures for competitive service contracts. For example, a state looking for help to meet the new Confined Animal Feeding Operation (CAFO) or Comprehensive Nutrient Management Plan (CNMP) requirements might put out a bid package to the private sector to provide those services.

All technical service providers will be required to certify that their work meets NRCS standards. NRCS will conduct random inspection of the work done by technical service providers. If there are long-term problems with the quality, the service provider will be decertified. Disputes between producers

\section{Build an effective technical services infrastructure}

The following is excerpted from a Soil and Water Conservation Society report, Seeking Common Ground for Conservation, How Conservation Measures Up in the Farm Security and Rural Investment Act of 2002 released in Jine 2002. The complete report can be found on the Society's website under the "Seeking Common Ground" logo on the homepage or at http://www.swcs.org/t_seeking_intro.htm.

Technical services-research, education, and technical assistance - are the foundation of conservation. The strength and effectiveness of the technical services infrastructure, more than any other factor, will determine how big the pay off from the Farm Security and Rural Investment Act of 2002 (FSRI 2002) will be for taxpayers and producers.

At a minimum, the Administration should ensure that CCC funding of technical assistance is sufficient to ensure that (1) producers have timely and effective access to the technical assistance they need and (2) taxpayers har- vest tangible improvements in environmental quality from their investment in conservation. These two objectives will best be achieved through a strategic investment of CCC funds for technical assistance in three key areas: (1) strengthening the number and technical capacity of NRCS staff at all levels, (2) entering into cooperative agreements with nonfederal governmental and nongovernmental organizations, and (3) securing the services of certified third-party vendors.

Settling for strategic investment of CCC technical assistance funds, however, would be a mistake. The

Administration should pursue a coordinated investment plan to build a modern technical services infrastructure that will deliver for taxpayers and producers. That investment plan should couple CCC funds for technical assistance with strategic increases in discretionary spending for research, education, and technical assistance. The first priority of a coordinated investment plan should be to strengthen the scientific and technical support available to governmental and nongovernmental field staff and technical advisors. 
NRCS helps the producer evaluate the resource conditions on their land to determine the most appropriate way to meet the producer's conservation objectives.

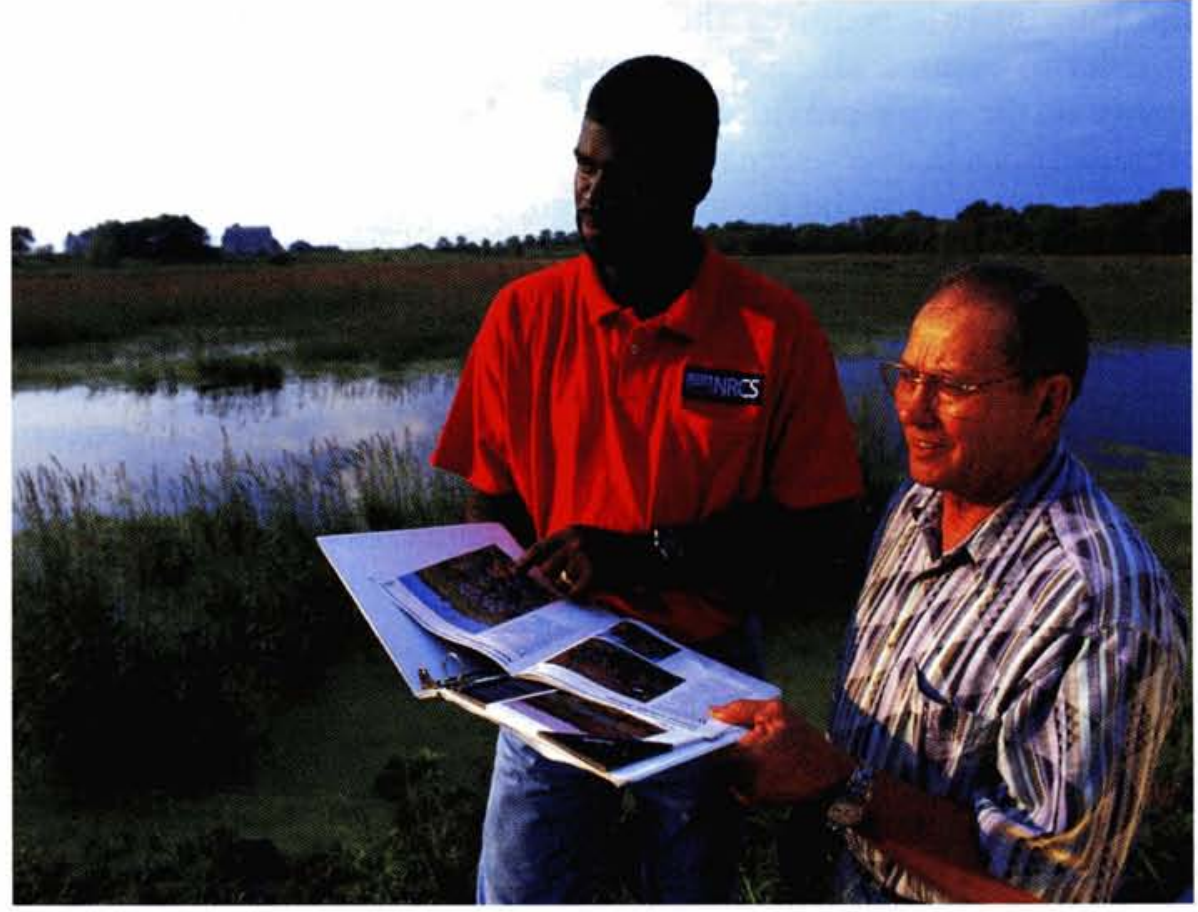

and technical service providers go through an appeals process set up by the NRCS state conservationist.

If a producer only wants NRCS to do the work that's fine Swenson says. "We're not going to run away from our customers."

\section{What are the benefits?}

"NRCS is stretched way too thin," agrees New York State dairyman John Noble, who milks 3,500 head at two farms and uses a private company for nutrient management and crop rotation knowledge. In his experience the company has been more responsive. "Timeliness in our business is an issue," he says. Technical service providers offer more options for producers and some can offer special expertise. "I don't have time to keep up with all the regulatory and technology changes."

Noble is installing a methane digester at one farm and relied on knowledge from private service providers. They can help you build innovation into your system he says. And in this case, a private firm will actually provide technical oversight on the digester through the Internet.

Lots of producers will be happy to do more conservation in exchange for some new funding observes, Pat McConnell, a consultant in Walla, Walla, Washington and former Certified Crop Adviser chair. It costs money to shift to reduced tillage or change rotations and there is some risk involved for producers. Some can't afford to take any risks without some additional cash McConnell says.

The program designers see flexibility as a priority. NRCS will set out the minimum requirements but wants to give each state the flexibility to design an accreditation system that suits their needs. The different topography of each state requires different conservation management solutions. "We want locally led common sense solutions to conservation," says Chief Knight.

Jett believes the addition of certified technical service providers will bring farmers and ranchers more flexibility and options. And that it will accelerate the delivery of conservation services and provide more innovative ideas.

\section{What are the challenges?}

From the technical service provider perspective McConnell says its important that there aren't drastic differences in how each State sets the rules and requirements. Many technical service providers work in more than one state. And it's important that those rules prevent situations where technical service providers end up competing with NRCS or Conservation Districts.

McConnell says there are still many unanswered questions. After a nutrient management plan is written, who is responsible for ensuring it's followed and who's on the hook if there's a problem, he asks. 
The interim rule requires the technical service provider to assume all legal responsibility for the quality of the work provided, but this doesn't answer questions in every scenario.

"Certification must be rigorous," argues Richard Wildman of Agriculture Consulting Services in Rochester, New York. Chief Knight is wrong about the need to build an industry says Wildman; the industry will build itself as long as there is a market. NRCS should focus on developing this market by ensuring long-term stable funding for conservation, establishing a clear and consistent set of standards, and ground rules about how technical services will be implemented.

Wildman sees NRCS's role shifting to provide their expertise to technical service providers who will then work with landowner's on the detailed planning and implementation of conservation measures. "I think that will be more efficient and effective since we can more easily gear up to meet the market demands."

There will be a lag time before companies like Wildman's make major investments to increase their ability to deliver services to more landowners. "It's unclear how it's going to play out right now. We won't be jumping on any TSP bandwagon," he says.

Another challenge with this initiative is what some call the "technical expertise gap." When using technical service providers instead of a government agency, it means you're one step removed from the decision making process which can be a problem sometimes.

Dave Swaim, an independent crop consultant in western Indiana, observes that, "It could be an exciting opportunity or a real disappointment." Based on his experience, Swaim is leaning towards the latter. He foresees independents as being more seriously challenged than agency and industry-based service providers in recouping the additional training and certification costs as well as the purchase price of new mapping software and GPS equipment.

Swaim worries that technical service providers could find themselves competing directly or indirectly with NRCS staff who will have the advantage of "paid" training, equipment and office support. Rules and policies under which technical service providers operate may favor NRCS or be too cumbersome. Swaim adds, "I'd like to at least see us all on a level playing field. Better yet, us working as a team, each doing what we can do best." NRCS and possibly extension departments will be helping train the technical service providers, so will bear some of the costs associated with training.

The current focus of conservation programs is on individual practices, especially waterways, manurehandling facilities and nutrient management plans. Eventually whole farm planning will be needed to integrate individual practices ranging from erosion control and wildlife habitat enhancement effectively into a complete package says Swaim. Certified conservation planners can provide the general assistance needed in developing and upgrading these comprehensive plans, but in the past primarily NRCS and state government staff have had regular access to the necessary training for this certification. A new effort will need to be made to bring independent technical service providers into the mix he says.

A final over-reaching concern for Swaim is vertical integration on the service side of agriculture and whether the new technical service provider policies will hasten this trend. He observes that a high percentage of the Certified Crop Advisors, not employed by academic and research institutions, work for seed and fertilizer companies and must therefore guard against potential conflicts of interest.

"This is a big change for everyone," says NRCS's Swenson. Some private sector and non-profits will jump at this in some areas but not in all cases. Producers won't notice the change immediately but in a year or two from now there will be a distinct difference.

"I'm excited about it because many more people will be involved in the science and art of conservation. And that can't be anything but good."

Article written based on interviews by Stephen Leahy.

Reprinted with permission from the Journal of Soil and Water Conservation. 